\title{
PEMBUATAN ALAT PENGUKUR KEEMPUKAN DAGING (MEAT SHEAR FORCE) DARI MODIFIKASI DUDUKAN ALAT BOR (VERTICAL DRILL STAND)
}

\author{
Mugianton ${ }^{1, *}$, Bambang Wahyudi ${ }^{2}$ \\ ${ }^{1}$ Lab. IImu dan Teknologi Daging Fakultas Peternakan UGM. \\ e_mail : mugi anton@ugm.ac.id \\ ${ }^{2}$ Lab. Hijauan Makanan Ternak dan Pastura Fakultas Peternakan UGM
}

Submisi : 18 Oktober 2018; Penerimaan : 10 Februari 2019

\begin{abstract}
ABSTRAK
Telah dilakukan penelitian tentang pembuatan alat pengukur keempukan daging/meat shear force (MSF). Tujuan penelitian adalah mengembangkan peralatan laboratorium yang lebih murah, bermanfaat dan dapat diaplikasikan pada kegiatan praktikum maupun penelitian. Alat ini merupakan modifikasi dudukan bor /vertikal drill stand dengan menambahkan : dudukan timbangan/scales holder, dudukan plat pemotong dan penutup alas. Penelitian diawali dari membuat rancangan dan menggambar desain alat, persiapan alat, bahan dan proses pembuatan, uji coba kinerja alat, menyusun instruksi kerja, evaluasi alat menggunakan kuisoner dari responden mahasiswa. Data pengukuran oleh responden mahasiswa menggunakan alat meat shear force (MSF) dan alat Warner-Bratzler shear force (WBS) pada sampel sosis merek tertentu menunjukkan nilai rerata keempukan relatif sama sekitar $0,8 \mathrm{~kg} / \mathrm{cm}^{2}$, sehingga alat pengukur keempukan daging dapat digunakan untuk menentukan nilai keempukan suatu sampel dengan baik.
\end{abstract}

Kata kunci : meat shear force, modifikasi, vertikal drill stand, keempukan daging

\section{LATAR BELAKANG}

Laboratorium IImu dan Teknologi Daging merupakan satu di antara 13 laboratorium yang berada di Fakultas Peternakan UGM. Kegiatan utama laboratorium ini meliputi praktikum, penelitian dan pengujian. Jumlah mahasiswa yang mengikuti praktikum laboratorium ini cukup banyak. Data terakhir tahun ajaran 2016/2017 semester ganjil melayani praktikum IImu dan Teknologi Daging dengan jumlah peserta 145 orang, dan semester genap melayani praktikum Teknologi dan Indutri Daging Unggas, dan praktikum Anatomi Histologi dengan jumlah peserta 120, dan 259 orang, sedangkan mahasiswa penelitian tugas akhir, di semester ganjil 15 orang, dan di semester genap 21 orang. Untuk kelangsungan kegiatan tersebut ketersediaan alat dan bahan merupakan hal yang penting karena semakin banyak peserta praktikum kebutuhan alat dan bahan yang digunakan tersebut semakin bertambah. Ketersediaan alat merupakan kendala pada kegiatan ini karena harga alat laboratorium yang mahal sementara alokasi anggaran untuk kebutuhan praktikum sangat terbatas. Anggaran praktikum sebagian besar digunakan untuk belanja bahan, sedangkan alokasi alat relative kecil. Untuk mengatasi permasalahan tersebut maka membuat alat untuk menguji keempukan daging Imeat shear force (MSF) merupakan altenatif untuk memenuhi kebutuhan praktikum dan penelitian. Alat ini merupakan alat yang digunakan untuk menentukan kualitas fisik dari sampel daging terutama menentukan nilai keempukan/tenderness.

Alat ini dibuat dengan menggunakan bahan dudukan bor Ivertikal drill stand, yaitu dengan 
menambahkan komponen antara lain : 1. dudukan timbangan/scales holder, 2. dudukan plat pemotong. Prinsip kerja alat ini cukup sederhana dengan mengacu pada alat Warner-Braztler Meat shear force, yaitu mengukur kekuatan serabut otot pada luasan tertentu. Untuk memotong serabut otot tersebut dengan menggunakan plat pisau dengan tebal $1.00 \mathrm{~mm}$ berbentuk segi lima yang dilengkapi alat pengukur berat pada alat vertikal drill stand. Plat pisau ini memiliki lubang sisi $3 \mathrm{~cm}$ segitiga pada bagian tengah berfungsi untuk meletakkan sampel daging. Bentuk lubang merupakan segitiga sama sisi sehingga mempunyai sudut salah satu sisinya $60^{\circ}$. Plat pisau ini akan memotong serabut otot daging dengan luasan tertentu sampai putus. Besaran keempukan dinyatakan dengan besaran tekanan yang diperlukan untuk memotong serabut otot tersebut dengan satuan $\mathrm{kgf}$ atau $\mathrm{kg} / \mathrm{cm}^{2}$.

Bentuk dan ukuran plat pisau sangat spesifik. Wheeler, dkk. (2001) menyatakan beberapa kriteria dari pisau geser Warner-Bratzler meliputi: 1) ketebalan pisau $1,016 \mathrm{~mm}$, 2) pisau pemotong berbentuk $\mathrm{V}$ (sudut 60 derajat), 3) ujung tombak miring sampai setengah putaran, 4) sudut $V$ harus dibulatkan sampai seperempat dari lingkaran berdiameter $2.363 \mathrm{~mm}, 5$ ) spacer yang menyediakan celah pisau pemotong untuk meluncur harus setebal $2.032 \mathrm{~mm}$. Penelitian tentang alat pengukuran keempukan daging telah dilakukan beberapa peneliti. ArantesPereira, dkk. (2016) membandingan pengukuran keempukan sampel longissimus thoracis et lumborum (BLTL), Tensor fasciae latae (BTFL),Semitendinosus (BST), Psoas major (BPM), Biceps femoris (BBF) dan Longissimus thoraciset lumborum (PLTL) menggunakan alat Texturometer dengan Warner-Bratzler. Hasil pengukuran texturometer dengan tebal pisau $1 \mathrm{~mm}$ tidak jauh berbeda dengan pengukuran menggunakan Warner Bratzler shear force. Beberapa parameter yang mempengaruhi nilai keempukan suatu sampel daging antara lain ukuran serabut otot, jenis otot dan jenis daging. Zhang dan Mittal (1993) melakukan pengukuran keempukan menggunakan Warner-Bratzler pada sampel salami dan pastrami. Pengukuran dilakukan dengan variasi diameter 10, 15 dan $15 \mathrm{~mm}$ pada kecepatan $250 \mathrm{~mm} /$ menit. Silva, dkk. (2017) melakukan pengukuran keempukan pada daging sapi menggunakan Warner-Blatzler dengan 2 variasi bentuk penampang yaitu bentuk bulat dan persegi. Sampel longsimus dorsi dengan penampang persegi cenderung lebih besar dari pada penampang bulat. Sehingga pengukuran dengan Warner-Blatzler sampel dengan bentuk persegi merupakan metode yang lebih tepat. Perlakuan dan penanganan sampel sebelum sangat diperlukan karena akan mempengaruhi nilai dari pengukuran. Lu dan Chen (1999) melakukan pengukuran pada daging sapi mentah dan daging sapi yang dipanaskan pada suhu tertentu. Pengukuran dilakukan menggunakan Warner-Bratzler (WB). Sampel yang digunakan menggunakan 4 jenis otot yaitu biceps femoris (BF), longissimus dorsi (LD), semimembranosus (SM), dan semitendinosus (ST). Nilai keempukan daging mentah cenderung lebih kecil dari pada setelah dipanaskan.

Alat pengukur keempukan ini diharapkan dapat dimanfaatkan mahasiswa dan diaplikasikan pada kegiatan praktikum dan penelitian yang berkaitan dengan pengujian kualitas fisik daging. Efisiensi biaya pembuatan dan perawat alat. 


\section{METODE PENELITIAN \\ Alat}

Peralatan yang digunakan dalam penelitian ini gergaji besi, alat las maestro MMA120 900WATT, bor Bosch GSB550, mata bor nachi $6 \mathrm{~mm}$, dinamo spin, kapasitor smf, genset maestro 70000 LE, mesin gerinda tangan Hitachi G10SS, ragum Wipro 6".

\section{Bahan}

Bahan yang digunakan dalam penelitian ini antara lain : dudukan bor /vertikal drill stand wipro DS 500,mur baut M10x25, U baut pipa penjepit M10, timbangan gantung digital/elektronic hanging scale DLE-75, battery alkaline AA, besi siku $3 \times 3 \times 3 \mathrm{~mm}$, besi strip $3 \times 25$ $\mathrm{mm}$, eletroda RD 260, cat spray pylox 6611300 cc warna blue white, sosis ayam merk champ $375 \mathrm{~g}$.

\section{Cara kerja}

Pada kegiatan ini terdiri atas beberapa tahap yaitu:
1. Membuat rancangan dan gambar alat MSF

Kegiatan ini dimaksudkan untuk memperoleh ukuran, komponen alat, bentuk keseluruhan secara visual. Pengerjaan rancangan dan gambar ini saya lakukan menggunakan program Corel Draw X7 dan kami sajikan dalam bentuk gambar dua dimensi. Gambar rancangan alat MSF yang kami usulkan disajikan pada gambar 1. Alat ini terdiri dari beberapa bagian antara lain : Statif/ tiang penyangga menggunakan besi bulat dengan diameter $19 \mathrm{~mm}$, panjang $60 \mathrm{~cm}$, timbang gantung digital maksimal $75 \mathrm{~kg}$, mata pisau mata pisau berlubang dengan bentuk segitiga sama sisi panjang $3 \mathrm{~cm}$ dan sudut $60^{\circ}$.dan 1 pasang plat dari baja stainless steel dengan tebal masing-masing $1 \mathrm{~mm}$ dan $4 \mathrm{~mm}$. Peer baja dengan diameter $2 \mathrm{~cm}$, panjang $20 \mathrm{~cm}$. Tuas mengunakan pipa besi $1.5 \mathrm{~cm}$, sedangkan alas dari plat besi siku $3 \mathrm{~cm}$.

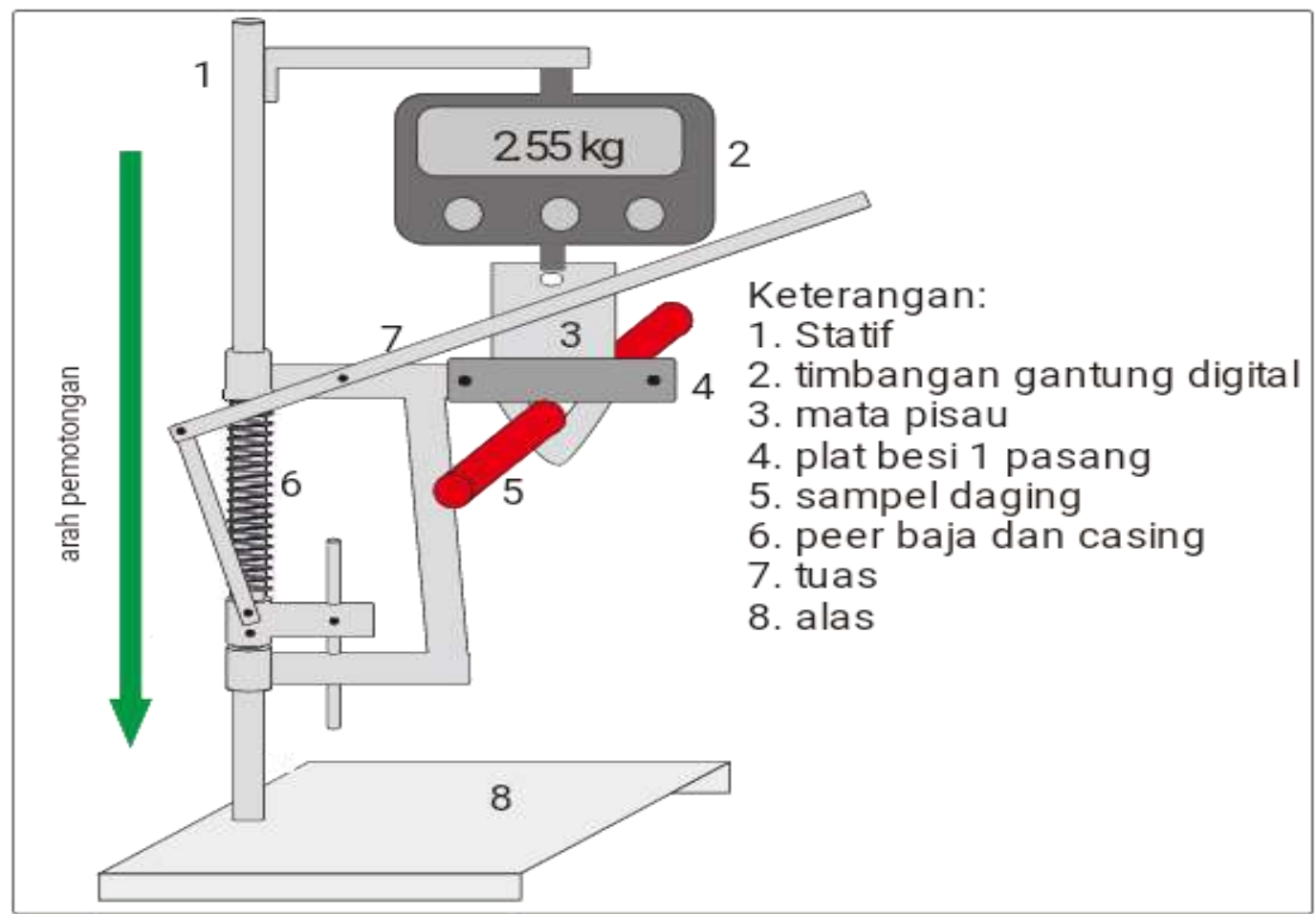

Gambar 1. Rancangan gambar alat MSF 
2. Persiapan alat, bahan dan proses pembuatan

Alat ini merupakan modifikasi dudukan bor /vertical drill stand, yaitu dengan menambahkan komponen antara lain : 1. dudukan timbangan/scales holder, 2. dudukan plat pemotong dan 3. penutup alas. Adapun tahap pembuatan meliputi : pemotongan, pengelasan, penghalusan, pengecatan dan finishing.

3. Uji coba kinerja alat

Uji kinerja ini alat adalah membandingkan hasil pengukuran sampel sosis menggunakan 2 jenis alat yaitu dengan alat Warner-Bratzler shear force (WBS) dan meat shear force (MSF). Masing-masing pengukuran dilakuan sebanyak 18 kali yang kemudian hasil pengukuran dihitung nilai rerata dan standar deviasi menggunakan MS Excel.

4. Menyusun instruksi kerja Instruksi kerja alat ini dimaksudkan untuk memberi petunjuk yang disediakan untuk membantu seseorang dalam mengoperasikan alat pengukur keempukan dengan baik dan benar.

5. Evaluasi alat menggunakan kuisoner dari responden mahasiswa

Yaitu dilakukan dengan menggunakan responden mahasiswa yang telah dipilih secara random/acak sebanyak 12 mahasiswa. Masingmasing mahasiswa dikumpulkan, dijelaskan tentang nama alat, instruksi kerja alat, kemudian diminta untuk mengoperasikan alat dengan mengukur keempukan sampel sosis. Masingmasing pengukuran dilakukan 5 kali, kemudian hasil pengukuran disalin pada lembar kuisoner dan menuliskan saran/komentar pada lembar yang telah disediakan.

\section{HASIL DAN PEMBAHASAN}

Alat pengukur keempukan daging ini dibuat dari modifikasi dudukan bor /vertikal drill stand, yaitu dengan menambahkan komponen antara lain : 1. dudukan timbangan/scales holder, 2. dudukan plat pemotong dan 3. penutup alas, sehingga dapat digunakan sebagai alat untuk menentukan nilai keempukan/tenderness dari sampel daging dan produk daging. Komponen pertama membuat dudukan timbangan, yaitu menggunakan bahan besi plat

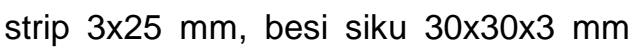
dan baut. Besi plat strip diukur dan dipotong dengan panjang $20 \mathrm{~cm}$, kemudian dibuat tekukan $7 \mathrm{~cm}$ dari salah satu sisi dengan sudut $90^{\circ}$. Potong besi siku dengan panjang $9 \mathrm{~cm}$ dan gabungkan dengan besi strip membentuk segitiga sama sisi menggunakan las listrik, kemudian rapikan dengan gerinda hingga permukaan rata, kemudian gabungkan pada tiang penyangga dengan 2 buah klem baut. Komponen kedua membuat dudukan plat pemotong yaitu menggunakan besi strip $3 \times 25 \mathrm{~mm}$. Potongan besi strip deng panjang 23 $\mathrm{cm}$, kemudian dibuat tekukan dengan sudut $90^{\circ}$, dengan jarak $3 \mathrm{~cm}$ dari sisi ujung. Langkah berikutnya membuat lubang sebanyak 4 titik yang berfungsi untuk menempatkan baut. Komponen ketiga membuat penutup alat, menggunakan bahan plat aluminium 1 $\mathrm{mm}$ berbentuk persegi empat dengan ukuran 20x20 cm, kemudian menempelkan pada alas menggunakan double tip.

Berikut urutan proses pembuatan alat pengukur keempukan daging disajikan pada gambar 2. Pemotongan bertujuan untuk memperoleh ukuran yang diinginkan, pengelasan bertujuan untuk menyambung dan merekatkan bahan logam, menghaluskan berfungsi untuk memperoleh bentuk yang rapi dan 
bersih, pengecatan berfungsi untuk melindungi logam dari korosi. Perakitan berguna untuk menggabungkan komponen-komponen

sehingga

diperoleh bentuk alat yang diinginkan.

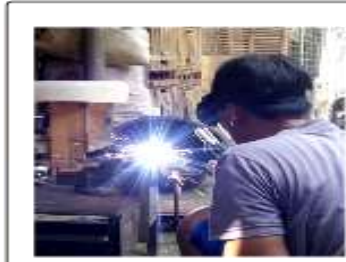

Pengelasan

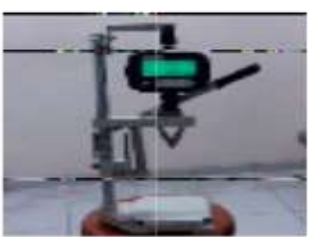

Produk

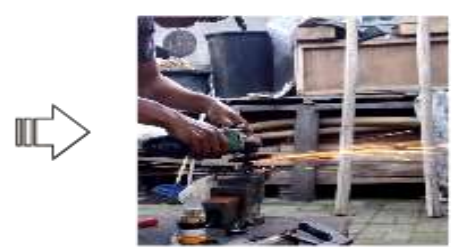

Menghaluskan

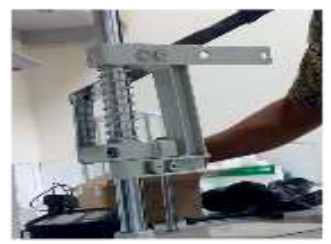

Perakitan

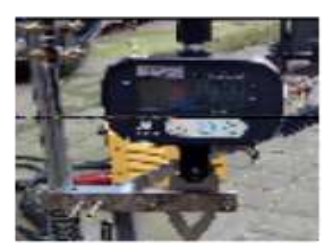

Produk sementara एy

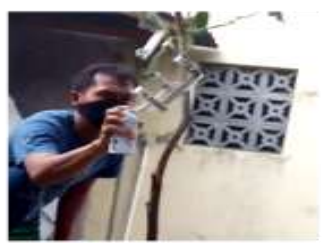

Pengecatan

Gambar 2. Tahapan proses pembuatan alat MSF

Finishing dan perakitan dari komponen-komponen diperoleh hasil akhir alat MSF yang disajikan pada gambar 3. Pengoperasian alat dilakukan dengan menekan tuas ke bawah secara

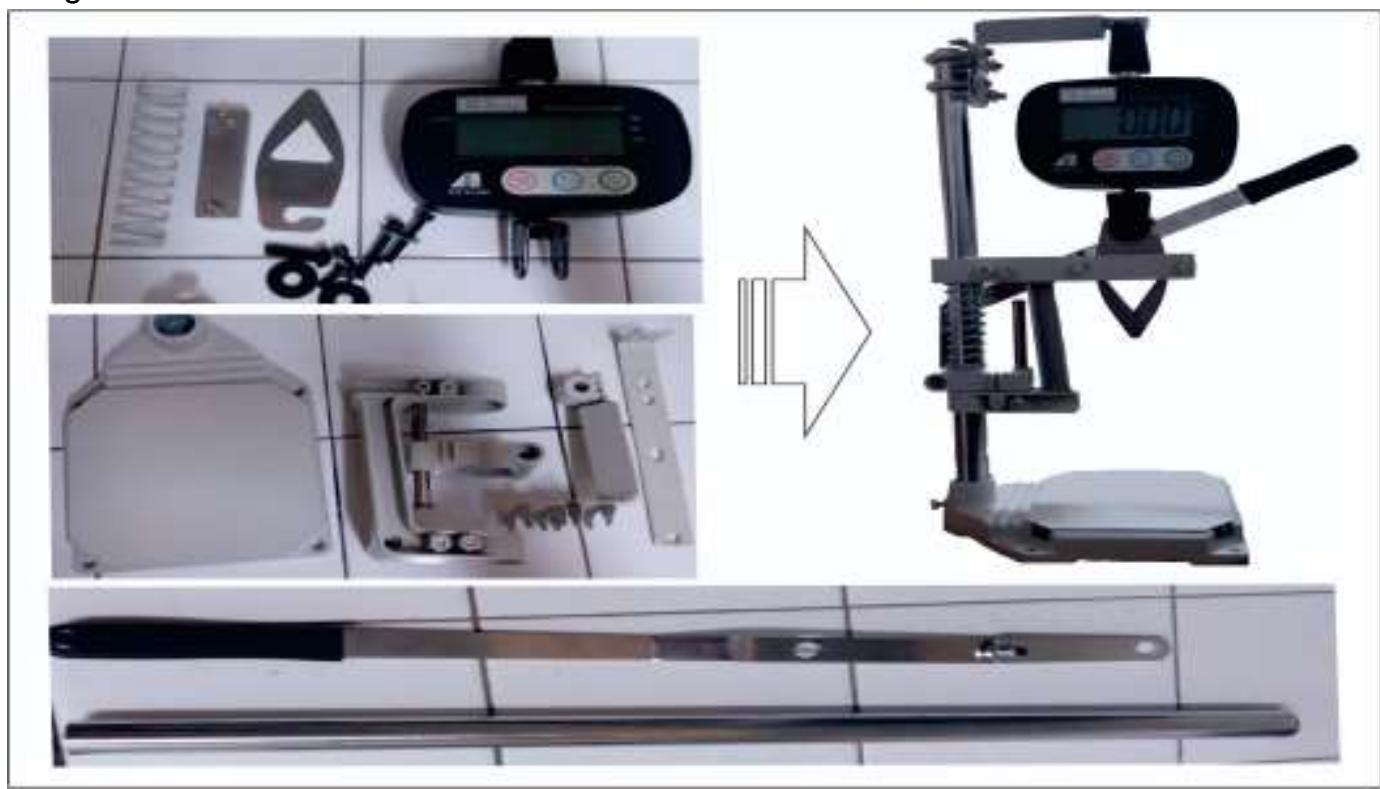

Gambar 3. Komponen komponen penyusun dan hasil akhir alat MSF

Uji coba alat ini saya mengunakan sampel sosis yang diperoleh di pasaran dengan merek tertentu. Sampel tersebut di thawing perlahan-lahan sambil mengamati perubahan angka pengukuran. Kemudian catat nilai yang tertinggi dari hasil pengamatan tersebut. 
Hasil pengukuran keempukan sosis disajikan pada tabel 1. Data diolah menggunakan MS Excel untuk

\begin{tabular}{|c|c|c|c|c|c|c|c|c|c|c|c|}
\hline No & 1 & 2 & 3 & 4 & 5 & 6 & 7 & 8 & 9 & $\begin{array}{c}\text { rerat } \\
\mathbf{a}\end{array}$ & std dev \\
\hline \multirow[t]{2}{*}{$\operatorname{MSF}\left(\mathrm{kg} / \mathrm{cm}^{2}\right)$} & 0,82 & 0,76 & 0,86 & 0,86 & 0,86 & 0,84 & 0,76 & 0,72 & 0,82 & 0,81 & 0,05 \\
\hline & 0,84 & 0,82 & 0,90 & 0,90 & 0,74 & 0,76 & 0,76 & 0,78 & 0,72 & & \\
\hline \multirow[t]{2}{*}{ WBS $\left(\mathrm{kg} / \mathrm{cm}^{2}\right)$} & 0,70 & 0,70 & 0,90 & 0,90 & 0,90 & 0,90 & 0,80 & 0,80 & 0,90 & 0,82 & 0,09 \\
\hline & 0,90 & 0,80 & 0,90 & 0,80 & 0,80 & 0,70 & 0,70 & 0,80 & 0,80 & & \\
\hline
\end{tabular}

menghitung nilai rerata dan simpangan baku.
Dari data tersebut menunjukkan bahwa rerata nilai keempukan relatif sama,yaitu sekitar $0,8 \mathrm{~kg} / \mathrm{cm}^{2}$ yang berarti nilai pengukuran keempukan sampel menggunakan alat WBS dan alat MSF relatif hampir sama sehingga alat pengukur keempukan daging modifikasi dapat digunakan untuk menentukan nilai keempukan suatu sampel dengan baik. Data perhitungan simpangan baku MSF lebih kecil dari WBS yang menandakan perbedaan setiap pengukuran sampel relatif kecil, hal ini menunjukan tingkat keterulangan pengukuran alat MSF lebih baik. Hal ini berkaitan dengan ketelitian dari timbangan digital dengan 2 digit pada MSF lebih baik dari pada timbangan analog yang hanya 1 digit pada WBS.

Langkah berikutnya adalah membuat intruksi kerja alat. Instruksi kerja alat ini dimaksudkan untuk memberi petunjuk yang disediakan untuk membantu seseorang dalam mengoperasikan alat pengukur keempukan dengan baik dan benar. Adapun instruksi kerja alat ini adalah sebagai berikut:

Kencangkan baut pemotong dan pastikan plat dan pisau pada kondisi bersih

1. Hidupkan timbangan dengan menekan tombol ON/OFF dan pastikan angka yang tertera menunjukan nilai Nol.
2. Potong sampel daging searah serabut otot dengan luas penampang 1 $\mathrm{cm}^{2}$ atau menyesauaikan.

3. Letak sampel pada lubang segitiga samasisi dan tekan tuas ke arah bawa hingga plat memotong sampel.

4. Amati perubahan angka pada timbangan dan catat nilai tertinggi dari pengukuran tersebut.

5. Ulangi pengukuran sebanyak 3 kali dan tentukan reratanya.

6. Matikan alat dengan menekan ON/OFF dan bersihkan alat seperti kondisi semula.

Evalusi penggunaan alat merupakan bagian yang sangat penting karena berkaitan dengan tingkat kepuasan dan kemudahan bagi para pengguna di dalam mengoperasikan alat. Pada evaluasi penggunaan alat saya menggunakan responden yang dipilih secara acak/random sebanyak 12 responden terutama pada mahasiswa yang pernah mengikuti kegiatan praktikum IImu dan Teknologi Daging. Hal ini dimaksudkan agar setiap responden telah memiliki pengetahuan tentang cara menentukan nilai keempukan menggunakan alat meat shear. Masing-masing mahasiswa dikumpulkan, dijelaskan kegunaan dan instruksi kerja alat, kemudian diminta untuk melakukan pengukuran dengan menggunakan 2 jenis alat pada sampel 
sosis yang diperoleh di pasaran. Pengamatan pengukuran untuk masingmasing alat dilakukan sebanyak 5 kali. Hasil pengukuran sampel oleh masingmasing mahasiswa tersebut kemudian disalin pada lembar kuisoner yang telah disediakan. Pada bagian akhir lembar kuisoner tersebut terdapat bagian saran/komentar sebagai masukan dari evaluasi alat. Dari hasil pengamatan masing-masing responden kemudian dilakukan pengolahan dengan menggunakan MS Excel untuk menentukan rerata dan simpangan baku. Data rerata pengukuran masingmasing responden disajikan pada tabel 2 berikut. Rerata pengukuran dengan MSF dan WBS masing masing responden menunjukkan nilai yang relatif sama yaitu $0,8 \mathrm{~kg} / \mathrm{cm}^{2}$. Ada beberapa data yang menunjukkan nilai simpangan baku yang relatif besar, hal ini menunjukkan bahwa faktor pengukuran tidak hanya dipengaruhi oleh ketelitian suatu alat, akan tetapi juga ketrampilan dan ketelitian pengguna dalam mengoperasikan alat tersebut. \begin{tabular}{lcrr}
\multicolumn{2}{c}{ Gambar } & 4 & merupakan \\
dokumentasi & dari para & responden \\
mahasiswa & ketika & sedang
\end{tabular} mengoperasikan alat. Dokumentasi ini diambil ketika responden dari mahasiswa ketika sedang melakukan pengukuran sampel sosis menggunakan 2 jenis alat penguji.

Tabel 2. Rerata dan standar deviasi pengukuran dari responden

\begin{tabular}{|c|c|c|c|c|c|}
\hline \multirow[t]{2}{*}{ No } & \multirow{2}{*}{$\begin{array}{l}\text { Res } \\
\text { pon } \\
\text { den }\end{array}$} & \multicolumn{2}{|c|}{$\operatorname{MSF}\left(\mathrm{kg} / \mathrm{cm}^{2}\right)$} & \multicolumn{2}{|c|}{$\begin{array}{c}\text { WBS } \\
\left(\mathrm{kg} / \mathrm{cm}^{2}\right)\end{array}$} \\
\hline & & Rerata & SD & rerata & SD \\
\hline 1 & $\mathrm{R} 1$ & 0,80 & 0,10 & 0,88 & 0,08 \\
\hline 2 & $\mathrm{R} 2$ & 0,86 & 0,12 & 0,98 & 0,13 \\
\hline 3 & R3 & 0,78 & 0,03 & 0,80 & 0,07 \\
\hline 4 & R4 & 0,77 & 0,11 & 0,98 & 0,19 \\
\hline 5 & R5 & 0,80 & 0,10 & 0,83 & 0,04 \\
\hline 6 & R6 & 0,81 & 0,05 & 1,08 & 0,13 \\
\hline 7 & R7 & 0,73 & 0,05 & 0,78 & 0,18 \\
\hline 8 & $\mathrm{R} 8$ & 0,83 & 0,04 & 0,70 & 0,07 \\
\hline 9 & R9 & 0,84 & 0,05 & 0,72 & 0,08 \\
\hline 10 & R10 & 0,72 & 0,09 & 0,78 & 0,11 \\
\hline 11 & R11 & 0,90 & 0,07 & 0,76 & 0,07 \\
\hline 12 & R12 & 0,72 & 0,13 & 0,62 & 0,04 \\
\hline
\end{tabular}
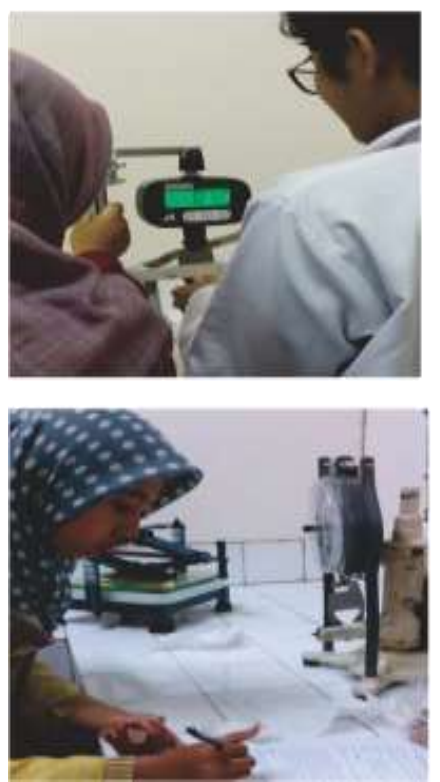
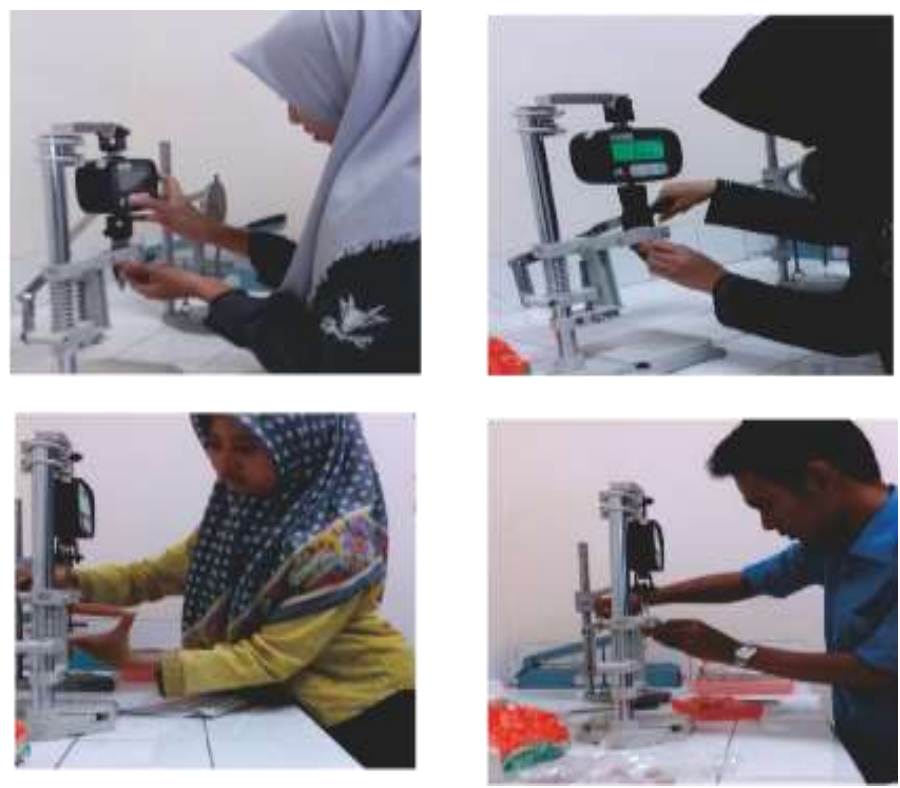

Gambar 4. Dokumentasi pengoperasian alat MSF dan WBS menggunakan sampel sosis 


\section{KESIMPULAN}

1. Alat pengukur keempukan daging/meat shear force (MSF) yang telah dibuat dari modifikasi dudukan bor /vertikal drill stand dapat digunakan pada kegiatan praktikum maupun penelitian dengan baik.

2. Data pengukuran nilai keempukan menggunakan MSF dan WBS relatif sama.

\section{SARAN}

Dari lembar komentar kuisoner responden mahasiswa yang telah dilakukan pengukuran sampel sosis dapat diperoleh saran sebagai berikut:

1. Pembacaan nilai terukur dengan digital sangat membantu daripada dengan analog, tetapi nilai tertinggi dari pengukuran tidak bisa berhenti secara otomatis sehingga harus lebih cermat didalam melakukan pengamatannya.

2. Dibutuhkan kecermatan dan ketrampilan didalam melakukan pengukuran untuk memperoleh hasil pengukuran yang maksimal.

\section{UCAPAN TERIMAKASIH}

Kami ucapkan terima kasih kepada Universitas Gadjah Mada atas dukungan dana kegiatan penelitian ini pada Program Hibah Inovasi Kreatif Tenaga Kependidikan tahun 2017

\section{DAFTAR PUSTAKA}

Arantes-Pereira, L., Vargas, F. C., Balieiro, J. C., Bittante, A. M. Q., \& Sobral, P. J. (2016). Reproducibility and correlation between meat shear force measurements by WarnerBratzler machine and a texturometer. International Journal of Food Studies, 5(2).

Lu, R., \& Chen, Y. R. (1999). Shear Properties and Warner-Bratzler Tenderness Measurement of
Beff. Journal of texture studies, 30(4), 361-375.

Silva, D. R., de Moura, A. P. R., Ramos, A. L., \& Ramos, E. M. (2017). Comparison of Warner-Bratzler shear force values between round and square cross-section cores for assessment of beef Longissimus tenderness. Meat science, 125, 102-105.

Wheeler, T. L., Shackelford, S. D., \& Koohmaraie, M. (2001). Shear force procedures for meat tenderness measurement. Roman L. Hruska US Marc. USDA, Clay Center, NE.

Zhang, M., \& Mittal, G. S. (1993). Measuring tenderness of meat products by Warner Bratzler shear press. Journal of food processing and preservation, 17(5), 351-367. 